\title{
SLC7A2 Gene
}

National Cancer Institute

\section{Source}

National Cancer Institute. SLC7A2 Gene. NCI Thesaurus. Code C119686.

This gene is involved in the transport of the cationic amino acids. 